\title{
A oração-amizade como um caminho de humanização em Santa Teresa de Jesus
}

\author{
Orientadora: Profa. Lúcia Pedrosa de Pádua \\ Pesquisadora: Valéria da Silva Pereira \\ Fonte: $\mathrm{CCPG}$
}

\section{Introdução}

Foi feito um estudo sobre a oração-amizade como caminho de humanização em Santa Teresa de Jesus. Aprofundamos o tema da amizade visto de vários ângulos, a saber: pela antropologia, filosofia, psicologia e pela teologia. A partir desses pressupostos vimos como a relação de amizade pode humanizar-nos, pois como disse o filósofo Aristóteles a amizade deve superar o nível do somente aprazível e utilitário e estabelecer-se na virtude, onde amamos o outro pelo que ele é, num amor gratuito e recíproco. A teologia nos mostra que Jesus fez da amizade um marco em sua missão e Santa Teresa, inspirada por sua profunda experiência Trinitária, nos mostrou como fez da oração-amizade um modo de ser amiga de Deus e de todos os homens e mulheres que desejam trilhar o cultivo da vida interior e passar pelo mundo fazendo o bem.

\section{Objetivos}

Pesquisar na perspectiva antropológica-filosófica o tema da amizade. Aprofundar a oração como relação de amizade na vida de Teresa de Jesus. Explicitar as consequências pastorais em nossa cultura e na experiência cristã, da oração/amizade com Deus. 